\title{
An Incidence of Multi-Year Sediment Storage on Channel Snowpack in the Canadian High Arctic
}

\author{
SCOTT F. LAMOUREUX,,${ }^{1,2}$ DANA M. McDONALD, ${ }^{1}$ JACLYN M.H. COCKBURN, ${ }^{1}$ MELISSA J. LAFRENIÈRE, ${ }^{1}$ \\ DAVID M. ATKINSON ${ }^{1}$ and PAUL TREITZ ${ }^{1}$
}

(Received 19 December 2005; accepted in revised form 24 May 2006)

\begin{abstract}
During June 2005, we identified the presence of sediment buried within multi-year channel snowpack of a small river located near Cape Bounty, Melville Island, Nunavut $\left(74^{\circ} 55^{\prime} \mathrm{N}, 109^{\circ} 35^{\prime} \mathrm{W}\right)$. Photographic evidence indicates that the sediment was deposited during the 2003 season by the initial meltwater flowing on the snowpack, which was dammed by snow upstream of a channel constriction. The resulting pond covered a minimum area of $180 \mathrm{~m}^{2}$ and contained an estimated minimum $27 \mathrm{Mg}$ of sediment. Suspended sediment measurements during the 2003 season indicate that deposition on the snowpack at this location represented $49 \%-65 \%$ of the sediment transport prior to the ponding and emplacement of the sediment on the snow, and approximately $20 \%$ of the measured sediment flux for the entire season. Multi-year snow accumulations immediately downstream exhibited similar sediment deposition on snow, but no evidence of multi-year sediment storage was present. By contrast, a similar stream in an adjacent watershed channelized rapidly, with minimal sediment deposition on the snow, and delivered a large pulse of sediment to the downstream lake. These results provide quantitative evidence for the magnitude of sediment storage on snowpack and point to the unique role that snow plays in the fluvial geomorphology of High Arctic watersheds.
\end{abstract}

Key words: hydrology, sediment transport, fluvial geomorphology, snow, meltwater ponding, sediment storage, Melville Island, erosion

RÉSUMÉ. En juin 2005, nous avons dénoté la présence de sédiment enterré dans une plaque de neige datant de plusieurs années d'une petite rivière située près de cap Bounty, sur l'île Melville, au Nunavut $\left(74^{\circ} 55^{\prime} \mathrm{N}, 109^{\circ} 35^{\prime} \mathrm{O}\right)$. D'après des preuves photographiques, le sédiment a été déposé pendant la saison 2003 par l'eau de fusion initiale s'écoulant sur la plaque de neige, qui avait été endiguée par la neige en amont d'un canal confiné. L'étang qui en a découlé recouvrait une aire minimale de $180 \mathrm{~m}^{2}$ et contenait, selon les estimations, au moins $27 \mathrm{Mg}$ de sédiment. Les mesures de sédiment en suspension pendant la saison 2003 indiquent que ce dépôt sur la plaque de neige à cet endroit représentait entre $49 \%$ et $65 \%$ du transport de sédiment avant l'accumulation d'eau et l'emplacement de sédiment sur la neige, et environ $20 \%$ du flux de sédiment mesuré pour toute la saison. Les accumulations de neige de plusieurs années immédiatement en aval comptaient des dépôts de sédiment semblables sur la neige, quoi qu'aucun emmagasinage de sédiment sur plusieurs années n'était présent. Par contraste, un cours d'eau similaire d'un bassin hydrographique adjacent s'est canalisé rapidement, avec peu de dépôts de sédiment sur la neige, puis a laissé une grande quantité de sédiment au lac en aval. Ces résultats fournissent des preuves quantitatives quant à l'ampleur de l'emmagasinage de sédiment sur la plaque de neige et laissent envisager le rôle unique que joue la neige sur la géomorphologie fluviale des bassins hydrographiques de l'Extrême-Arctique.

Mots clés : hydrologie, transport de sédiment, géomorphologie fluviale, neige, accumulation d'eau, emmagasinage de sédiment, île Melville, érosion

Traduit pour la revue Arctic par Nicole Giguère.

\section{INTRODUCTION}

Fluvial processes in the High Arctic have attracted considerable research attention because of the unique conditions of intense, short-lived discharge during spring snowmelt (Church, 1972; Woo, 1983; Clark, 1988), poorly vegetated catchments with the potential for high levels of sediment erosion (Woo and McCann, 1994), and the sensitivity of continuous permafrost regions to climate variability (Woo et al., 1992). Recent modeling work has suggested that sediment delivery from permafrost catchments may increase with projected warming and increased snowpack (Syvitski, 2002), but many uncertainties remain regarding the response of fluvial systems to future changes (Woo and McCann, 1994). One key uncertainty in these projections is the role that snow cover will play in sediment yield. Snowpack that occurs directly in the channel (hereafter, channel snowpack) plays an important role in sediment erosion and transport in Arctic nival systems by delaying flow behind snow dams, determining the location of initial

\footnotetext{
${ }^{1}$ Department of Geography, Queen's University, Kingston, Ontario K7L 3N6, Canada

${ }^{2}$ Corresponding author: lamoureu@ post.queensu.ca

(C) The Arctic Institute of North America
} 
channelized flow with respect to the summer channel and floodplain, and isolating flowing water from banks and bed in snow-walled channels. These snowpack effects are frequently most pronounced during the period of highest discharge and maximum potential erosion (e.g., Woo and Sauriol, 1980; Heginbottom, 1984; Forbes and Lamoureux, 2005). The interaction between sediment erosion and storage during the nival freshet has frequently been noted by researchers (e.g., McCann et al., 1972; Braun et al., 2000), but few cases have been quantitatively documented (c.f., Woo and Sauriol, 1981).

We report the occurrence of an episode of multi-year sediment storage on channel snowpack in the Canadian High Arctic, providing estimates of the mass stored and comparing sediment storage to suspended sediment transport in the same season. These results indicate that sediment on channel snowpack may represent a significant portion of catchment sediment yield and play an important role in interannual sediment storage in some Arctic catchments.

\section{STUDY LOCATION}

The study was carried out at Cape Bounty, located on the south-central coast of Melville Island, Nunavut $\left(74^{\circ} 55^{\prime} \mathrm{N}\right.$, $109^{\circ} 35^{\prime}$ W, Fig. 1). Work was focused on two adjacent watersheds-referred to here as the West $\left(9.5 \mathrm{~km}^{2}\right)$ and East $\left(11.4 \mathrm{~km}^{2}\right)$ watersheds (unofficial names) - that drain into similar small lakes. Streams in both watersheds drain rolling terrain incised into a broad plateau that rises to ca. $100 \mathrm{~m}$ above sea level. The area is underlain by steeply dipping sedimentary rocks of the Devonian Weatherall and Hecla Bay Formations and mantled with glacial and regressive early Holocene marine sediments (Hodgson et al., 1984). Continuous permafrost is present and forms an active layer ca. $0.5-$ $1 \mathrm{~m}$ deep during the melt season. Vegetation cover is heterogeneous and varies by drainage conditions, but it is generally characteristic of patchy dwarf prostrate shrub tundra in the region (Walker et al., 2005).

The severe polar climate results in long, cold winters and short, cool melt seasons from June through September. Winter snowfall is $83.6 \mathrm{~cm}$ (1971-2000 mean at Mould Bay, $200 \mathrm{~km}$ west of Cape Bounty) and extensively redistributed by winds. As in other High Arctic areas (Woo, 1983), the resultant snow distribution is variable, with highest accumulations in land concavities and stream channels. The snow distribution along channels at Cape Bounty is typically highly variable, ranging from deep accumulations in lower reaches to bare channels in some locations in the middle reaches. Mean daily July temperature at Cape Bounty (2003-04) was $3.1^{\circ} \mathrm{C}$. Summer rainfall is infrequent and typically of low intensity, but low stratus cloud and fog are common during the summer months.

Snowmelt typically begins in early to mid June, with initial streamflow beginning 10-20 days later. Deep snowfill in channels (locally $>4 \mathrm{~m}$ depth) and snowdrift dams (Woo and Sauriol, 1981; Heginbottom, 1984) often result in extensive ponding of meltwater and delay of open-channel flow by $1-8$ days. Stream discharge rises rapidly, and peak flow occurs several days later. Flow rapidly recedes as the snow is exhausted, and discharge is low for the remainder of the season. The abundance of unconsolidated sediment and clastic bedrock in the watersheds is reflected by high loads of suspended sediment (ranging from 400 to $\left.5500 \mathrm{mg} \cdot \mathrm{l}^{-1}\right)$ during the main snowmelt period.

\section{METHODS}

Observations of the sediment on channel snowpack were primarily photographic prior to 2005. Measurements of the residual sediment and snowpack were obtained after water levels had receded in late June 2005. The goal of the field measurements and sampling was to determine the extent and quantity of sediment and to identify the depositional context for the sediment and snowpack through stratigraphic and snow characteristics. Meteorological and hydrological and sediment deposition data from the "West Stream" and two lakes were used to provide further related information for study.

The spatial extent of the sediment was determined from exposure within the channel snowpack, and the presence and thickness of the sediment within the snow were determined using cores obtained by inserting a $7.6 \mathrm{~cm}$ aluminum pipe 1 to $1.5 \mathrm{~m}$ into the snow. The extent of the sediment was mapped with a Garmin GPS $( \pm 5 \mathrm{~m})$, and relative position between GPS points was verified to $\pm 0.5 \mathrm{~m}$ with a measuring tape. Sediment samples were obtained with a $100 \mathrm{~cm}^{3}$ rectangular sampler and weighed on site to $0.1 \mathrm{~g}$. In the laboratory, the samples were dried at $50^{\circ} \mathrm{C}$ and reweighed to determine bulk density. Five subsamples (ca. $200 \mathrm{mg}$ each), created by homogenizing sediment obtained from 12 sample locations, were used for particle size analysis with a Beckman Coulter LS200 laser scattering analyzer. Each subsample was run three times for 60 seconds with continuous sonication, the results from each subsample were averaged, and all subsample results were further averaged for each location. Snow samples from the snow profile on the west bank were collected, melted, vacuum-filtered through $0.45 \mu \mathrm{m}$ acetate filters, and stored without headspace in $20 \mathrm{ml}$ scintillation vials. The snowpack exposure was documented, and the snow and sediment units were identified and their thicknesses measured. Electrical conductivity and isotopic composition were used as means to differentiate snowpack from different seasons. The specific electrical conductivity was measured with a YSI Model 30M meter calibrated with a $10 \mu \mathrm{S} \cdot \mathrm{cm}^{-1}$ standard. Hydrogen isotope analysis was carried out using a Finnigan Mat 252 mass spectrometer at Queen's University Facility for Isotope Research (QFIR) ( $\pm 1 \%$ accuracy). Results are reported as standardized departures $(\delta)$ from Vienna Standard Mean Ocean Water (VSMOW).

A comprehensive hydrological and sediment transport monitoring program was established at Cape Bounty and 


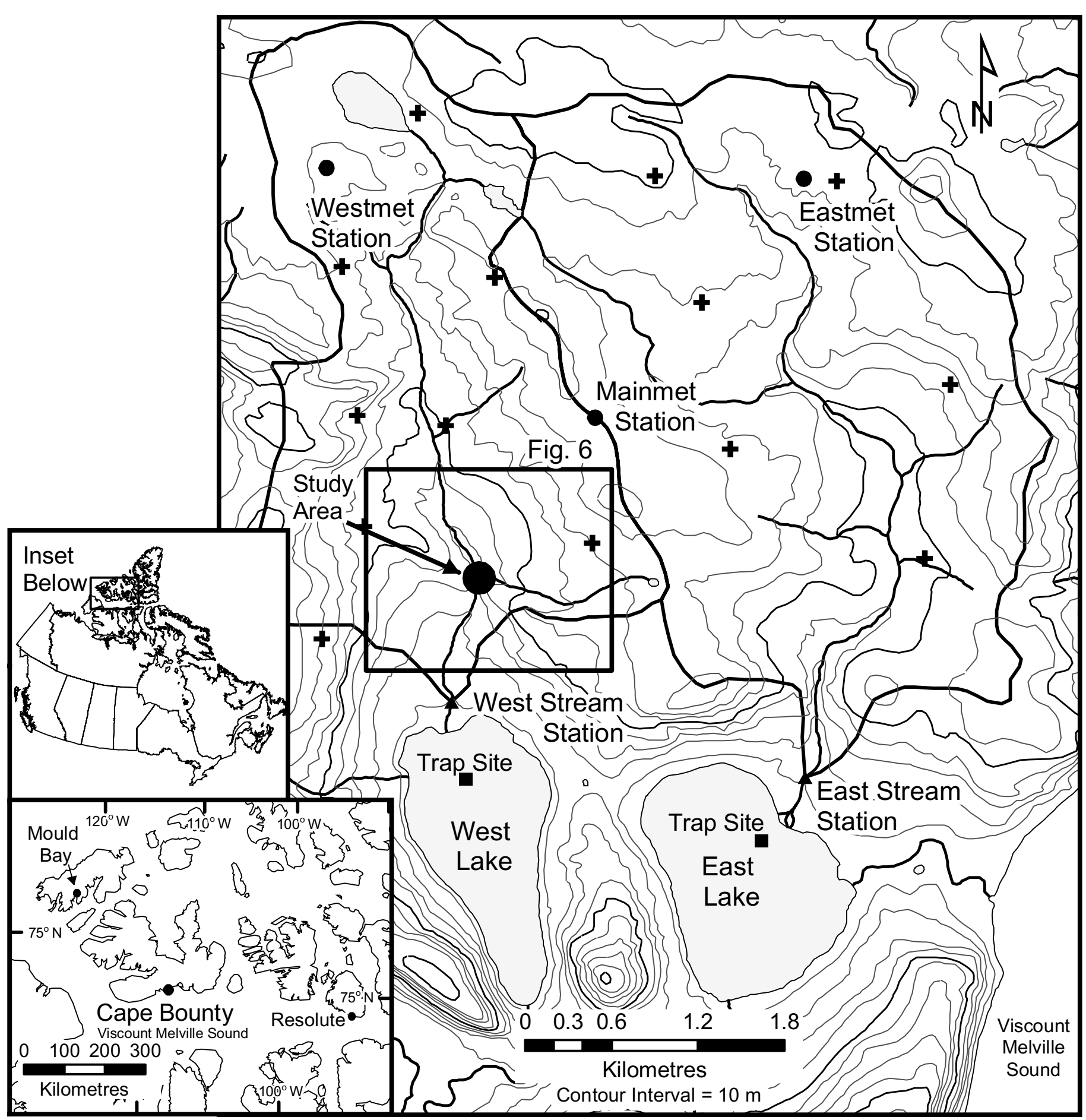

FIG. 1. The location of the Cape Bounty field site in Canada (small inset) and the High Arctic Islands (lower inset). The main map indicates the two study watersheds and the locations of the meteorological (circles), hydrological (triangles), and limnological (squares) monitoring stations. Snow survey transects are indicated by + symbols.

carried out during the 2003-05 melt seasons. A network of 13 snow survey transects was measured at the beginning of June to estimate snow water equivalence (SWE) for both watersheds (Fig. 1). Each transect comprised ten depth measurements and a single density measurement along a $100 \mathrm{~m}$ length. Mean SWE was estimated for each transect and spatially averaged for each watershed on the basis of units defined by major terrain types (channel, slopes, and plateau). Three weather stations (Mainmet, Westmet, and Eastmet, Fig. 1) established in 2003 measured and recorded temperature at $1.5 \mathrm{~m}$ above the ground at 10 -minute intervals with Onset Hobo $\mathrm{H} 8$ loggers $\left(0.4^{\circ} \mathrm{C}\right.$ accuracy) in all three study years. Precipitation was also measured with Davis industrial tipping bucket gauges $(0.2 \mathrm{~mm}$ resolution) and recorded continuously with Onset event loggers. 
Hydrometric measurements on both streams were obtained from stations near the lake inlets (Fig. 1). Stage was recorded in 2003 with Sensym SCX vented differential pressure transducers connected to Onset Hobo H8 loggers ( 2 mm calibrated accuracy) and recorded at 10-minute intervals. Discharge was rated at the stations using manual current measurements from a Columbia impellor meter approximately every second day ( $\mathrm{n}=24$ West, $\mathrm{n}=25$ East $)$ throughout the season, and resulted in well-constrained rating curves $\left(r^{2}=0.84\right.$ and 0.89 , respectively). Suspended sediment concentrations were obtained three times daily (at 0100, 0900, and 1700 in 2003) with a DH-48 manual sampler. Volumetric samples were vacuum-filtered through $0.45 \mu \mathrm{m}$ Isopore cellulose acetate filters. Filters were oven-dried at $50^{\circ} \mathrm{C}$ and weighed at least twice. Point measures of suspended sediment concentration were extrapolated to hourly values with a robust spline function. This method likely underestimates the quantity of sediment transported because it inevitably excludes short-lived pulses of high sediment concentration like those that were observed with more intensive sampling in subsequent years.

Sediment deposition in the lakes was measured with two traps, one for each lake (see Fig. 1). Traps were suspended from the ice pan and located $0.5 \mathrm{~m}$ above the lake bottom. They were recovered, and the receptacle replaced, at irregular intervals of 1 to 7 days. Traps were equipped with $50 \mathrm{ml}$ centrifuge tubes for collectors and funnels (12 cm diameter with $20 \mathrm{~cm}$ vertical walls) to increase capture and prevent loss due to lateral currents. Trap sediments and headspace water in the receptacle were returned to the laboratory, vacuum-filtered through $0.45 \mu \mathrm{m}$ Isopore filters, and air-dried to determine mass.

\section{RESULTS}

Streamflow in both catchments in 2005 was characterized by an early melt and short ( $<8$ hour) transition from ponding to flow in snow-walled channels. In contrast, ponding in the 2003 and 2004 seasons lasted more than six days. Streamflow in 2003 increased during the initial week of flow, reaching maximum discharge on 1 July (Fig. 2). Suspended sediment concentrations showed a similar pattern, but the highest concentrations were observed on 3 July. After peak snowmelt, discharge and suspended sediment concentration both receded. Several small rainfall events in July 2003 briefly raised discharge but had limited impact on sediment transport (Fig. 2).

After streamflow in the West Stream receded from the snowmelt peak in mid June 2005, the exposed snow walls revealed a contiguous unit of sediment within the snowpack (Fig. 3). The sediment was $0.10-0.15 \mathrm{~m}$ thick (mean $0.12 \mathrm{~m}$ ) and was exposed in section on the west bank (Fig. 3a, b). On the east bank, the snow above the sediment unit had ablated and revealed the upper sediment surface (Fig. 3c). Mapping of the sediment unit indicated that the unit extended $25 \mathrm{~m}$ along the long axis of the stream and a

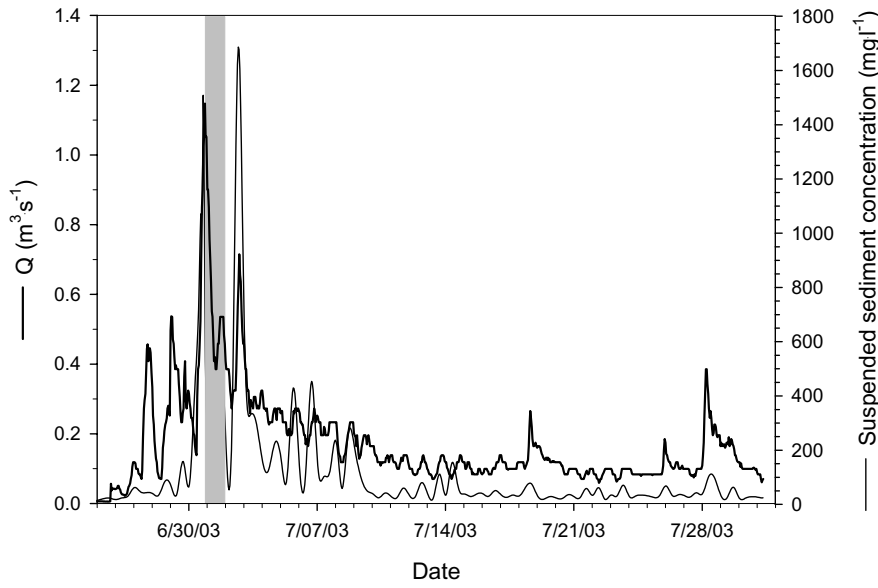

FIG. 2. Discharge and suspended sediment transport in the West Stream during the 2003 melt season. The shaded area corresponds to 1 July and is also shown in Figure 8.

maximum of $13 \mathrm{~m}$ normal to the channel, with a mapped area of $180 \mathrm{~m}^{2}$. Similar units were not observed in the 2005 channel snowpack in any other location (although in some locations the channel was incised more than $4 \mathrm{~m}$ and conditions were too dangerous to enter it). Based on the mean sediment dry bulk density $\left(1250 \mathrm{~kg} \cdot \mathrm{m}^{-3}, \mathrm{n}=7\right)$ and a mean depth of $0.12 \mathrm{~m}$, the dry mass of sediment contained in the $180 \mathrm{~m}^{2}$ area was estimated as $27 \mathrm{Mg}$ (megagrams).

Particle size analysis revealed a wide range of sizes within the sediment (mean $62.5 \mu \mathrm{m}$, standard deviation $32.9 \mu \mathrm{m}, \mathrm{n}=12$ ), although no grains larger than $2000 \mu \mathrm{m}$ were observed in the samples. The sediment was typically rich in sand $(7.9 \%-82.6 \%$ composed of particles larger than $62.5 \mu \mathrm{m}$ ) and in 7 of the total 12 samples the volumetric sand content was more than $65 \%$ of total volume. The highly variable particle size characteristics made it impossible to extrapolate size characteristics to the entire mass of sediment.

A survey of the snow-sediment exposure in the 2005 channel snowpack revealed four primary units (three of snow, one of sediment, Figs. 3, 4). Snow units 1 and 2 had a dense and relatively uniform structure. The upper snow unit (3) had lower density and was separated from the underlying unit (2) by a prominent ice layer (Fig. 4). Specific conductance of the snow water in unit 1 indicated dilute conditions, declining from the top to the bottom. A similar pattern of specific conductance was observed in snow unit 2, while conductance in the upper snow unit (unit 3) was relatively uniform. Hydrogen isotopes in the snow indicate different thermal histories for each unit, but the units were internally similar (Fig. 4). These results suggest that the snowpack encasing the sediment encompassed three distinct periods of snow deposition. The lowest unit predates the sediment emplacement, and the profile of specific conductance suggests diffusion of solutes downward from the overlying sediment. In the snow overlying the sediment (units 2 and 3), the hydrochemical and isotopic compositions above and below the hoar-ice complex separating the units similarly suggests solute 

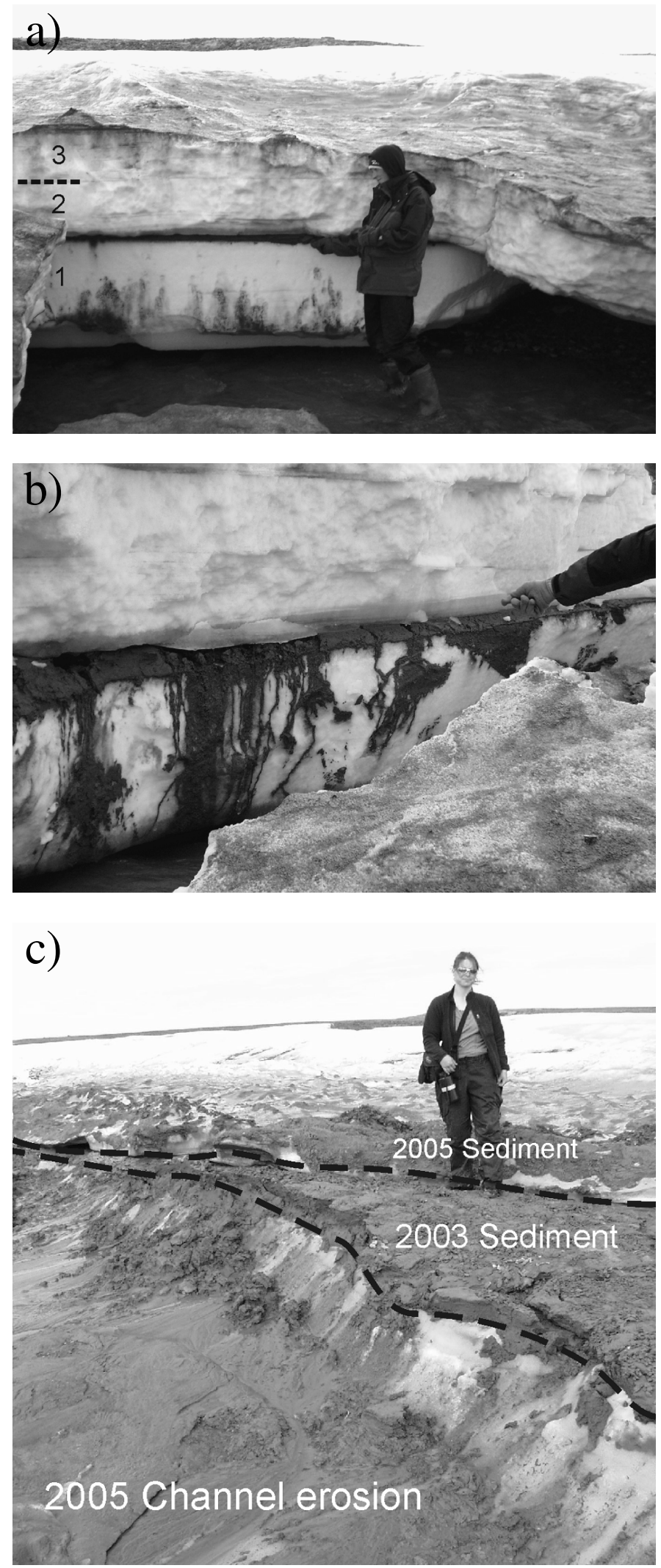

FIG. 3. Exposure of sediment (a, b) in the west bank on 22 June 2005 and (c) in the east bank channel snowpack on 28 June 2005. Numbers on the left margin of (a) correspond to snow units in Figure 4. On the east bank, opposite the area shown in (a), a large area of the overlying snowpack had ablated, superposing the thin, discontinuous 2005 sediment on the residual 2003 sediment surface (c). Buried 2003 sediment extends $6 \mathrm{~m}$ behind the person standing in the photograph.

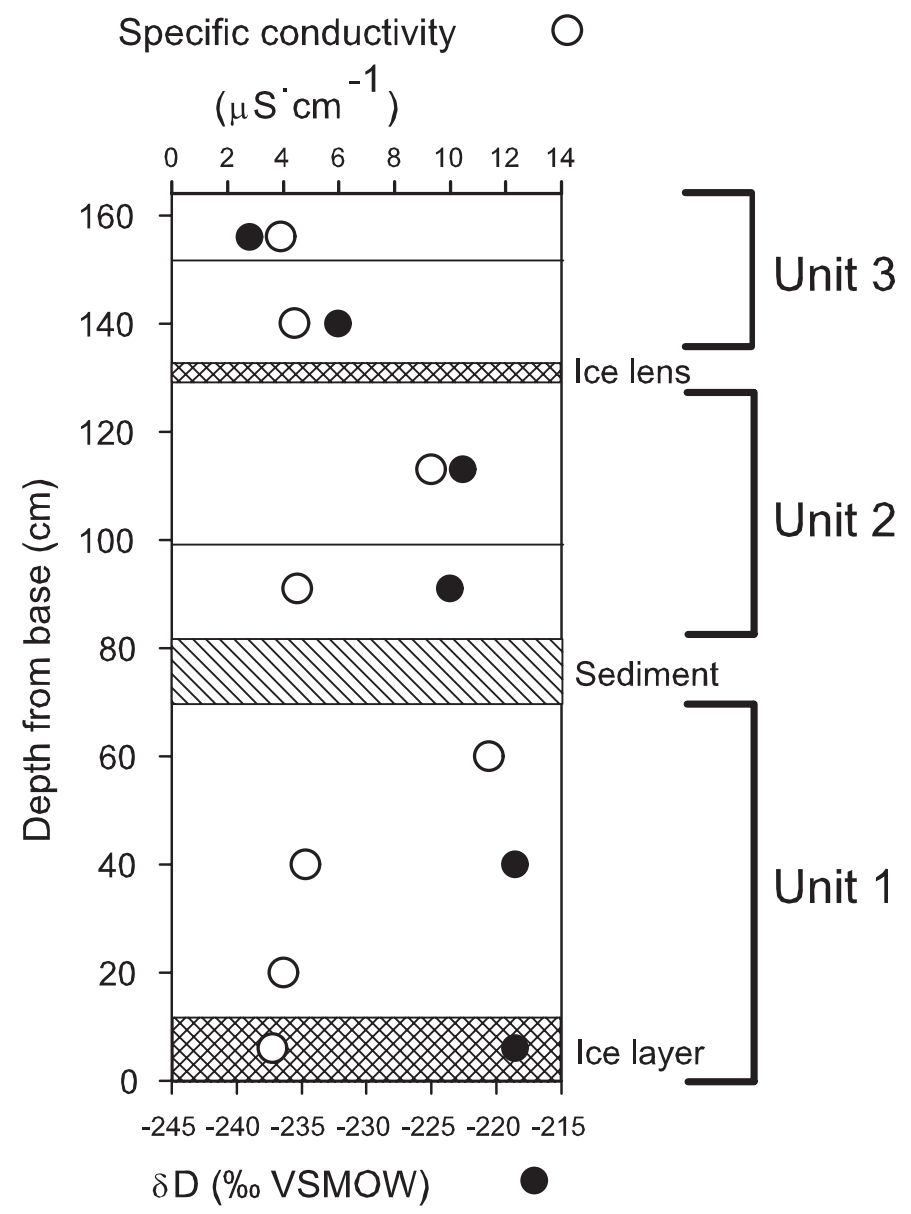

FIG. 4. Composite snow stratigraphy log and snow electrical conductivity and isotope data from west bank on 28 June 2005. Cross-hatching indicates ice lenses and diagonal hatching represents the sediment layer. Unit numbers correspond to references in the text. The snow section is shown in Figure $3 \mathrm{a}$.

diffusion in the middle snow unit (possibly from solute exclusion during freezing of the ice lens above), while the uppermost snow unit is isotopically distinct and of different origin than unit 2 .

The snow-sediment stratigraphy indicates that the encased sediment was deposited during the 2003 melt season. In that season, meltwater initially ponded on the snow behind a low snowdrift dam. On 1 July, a sub-nival channel was established and all meltwater was directed below the snow for the remainder of the season. As the water changed routing, a large area of sediment was left behind on the snow surface (Fig. 5a, b). Measurements taken in 2003 suggested the thickness of the sediment cover varied from 0.10 to $0.35 \mathrm{~m}$. However, a complete survey of the sediment was not conducted. Photographs from the 2004 melt season show that the snowpack adjacent to the 2004 channel was comparatively clean, and the extent of sediment deposition was minimal (Fig. 5c). Similarly, ponding in 2005 was short-lived and minimal sediment was deposited on the channel snowpack prior to the formation of the deep, snow-walled channel (Fig. 5d).

Direct measurements of residual snowpack and sediment cover were not collected at the end of 2003. However, an 

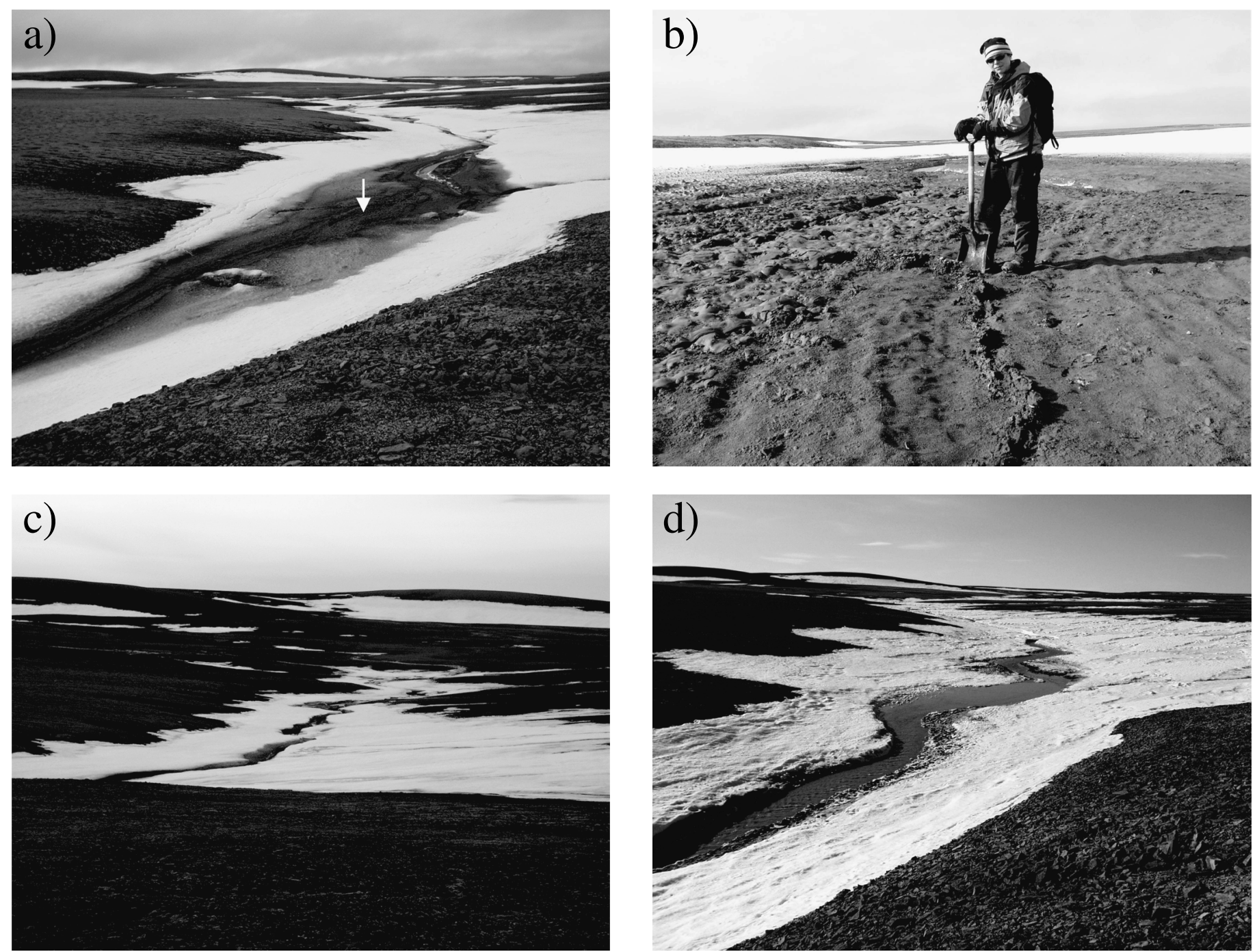

\section{d)}

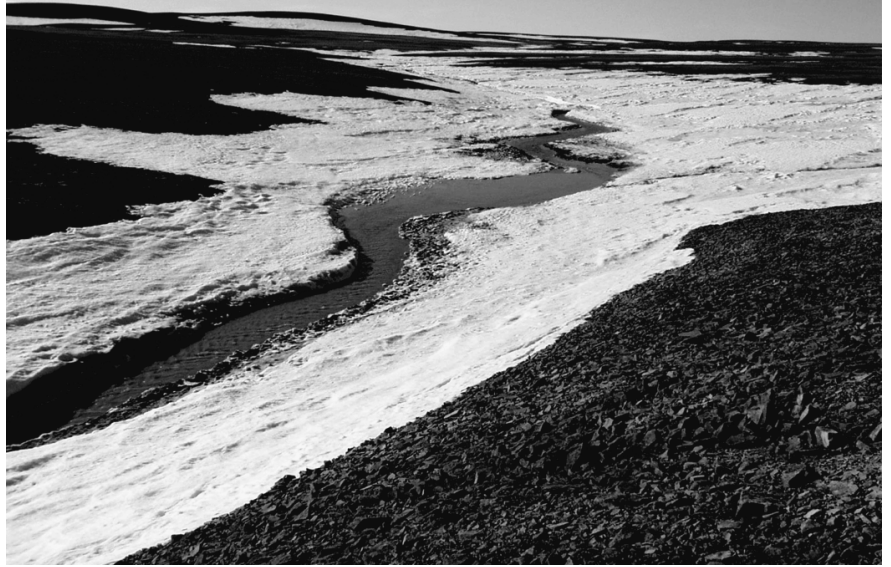

FIG. 5. Photograph sequence showing sediment deposition on the West Stream channel snowpack at the study area (Fig. 1). (a) Areal extent of sediment deposition on the channel snowpack on 2 July 2003. The white arrow shows location of close-up view (b) of that deposition (same location and date). (c) Areal extent of sediment cover on 2 July 2004; (d) Same location on 15 June 2005 (from a lower vantage point). Note the absence of sediment on the channel snow in 2004 and minimal sediment cover in 2005.

IKONOS satellite image obtained on 28 August 2003 indicates that snow remained in the West Stream channel at the location of the sediment deposit and with more extensive coverage $400 \mathrm{~m}$ downstream (Fig. 6a). Weather records at all stations indicate that 2 September was the last day with mean temperatures above $0^{\circ} \mathrm{C}$, suggesting that the snow captured in the IKONOS image remained until at least 2004. A similar image obtained on 22 July 2004 reveals extensive snow remaining in the channel and at the study site, although further melting likely occurred before the end of the 2004 season (Fig. 6b). The more extensive snow cover in 2004 reflects the higher SWE compared to the previous season (Table 1).

Finally, compared to the West Stream, the East Stream exhibited minimal initial meltwater ponding and began to flow six days earlier in 2003. Sediment deposition on the snowpack was minimal. Manual sampling of suspended sediment from the East Stream was done after initial flow began. However, sediment traps in the East Lake reveal that mean daily deposition in the lake during the first three days was the highest recorded for the entire season (Fig. 7a). A similar initial pulse of sedimentation was not apparent in the West Lake (Fig. 7b), probably because of the prolonged ponding and deposition of sediment on channel snowpack.

\section{DISCUSSION}

\section{Impact of Sediment Storage on Sediment Yield}

Although the sediment stored on the snowpack in the West Stream channel was unique in a number of ways, its presence is an important indicator of the role of snow in sediment storage in High Arctic fluvial systems. Woo and Sauriol (1981) noted similar sediment deposition on snow for a tributary of the McMaster River in 1977. They documented bed load transported by peak discharge of $0.4 \mathrm{~m}^{3} \cdot \mathrm{s}^{-1}$. The resulting $140 \mathrm{~m}^{2}$ deposit totaled $0.85 \mathrm{Mg}$. 

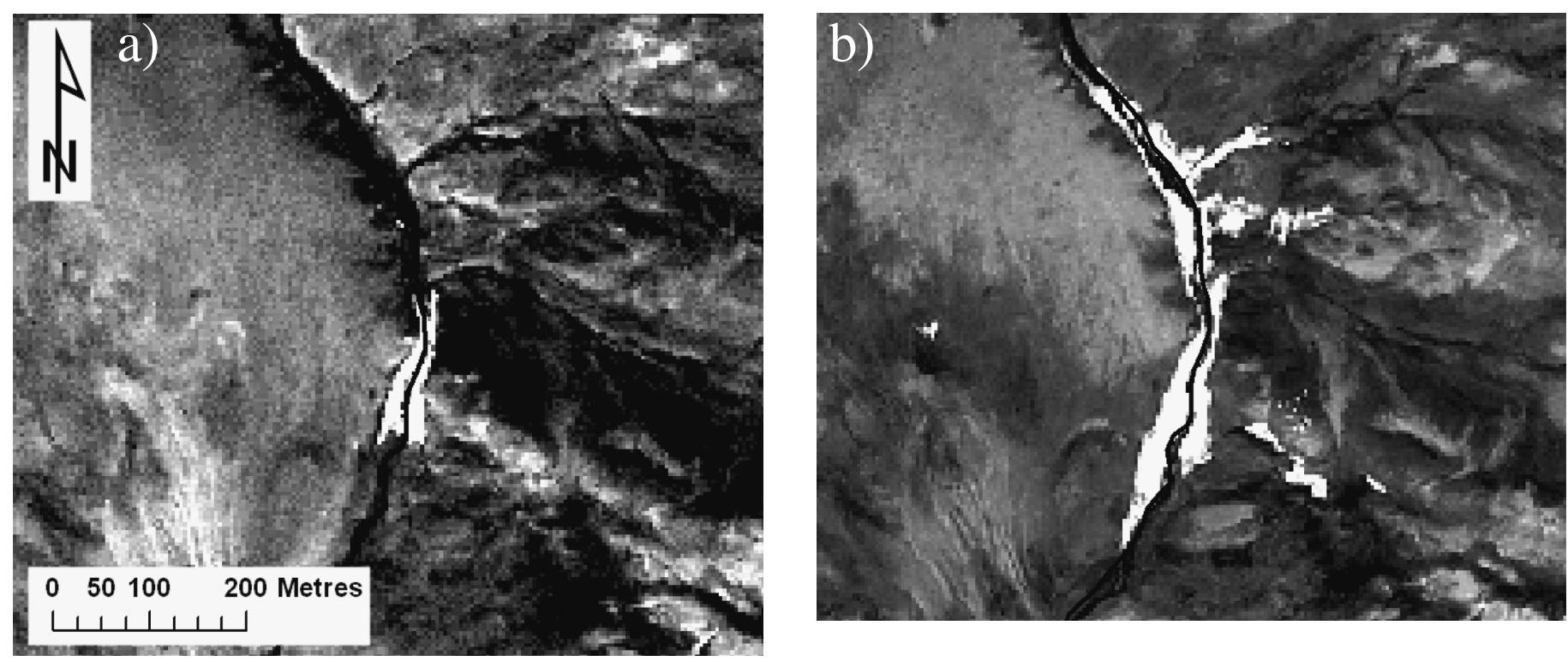

FIG. 6. IKONOS satellite images of Cape Bounty acquired (a) on 28 August 2003 and (b) on 22 July 2004 . The images are $800 \times 680 \mathrm{~m}$ subsets of full scenes, displayed as a grey-scale representation of a false colour infrared (NIR, R, G), and have a spatial resolution of $4 \mathrm{~m}$. The classified snowbank in the 2003 image is $150 \mathrm{~m}$ long and ranges in width from $20 \mathrm{~m}$ in the north to $48 \mathrm{~m}$ in the south.

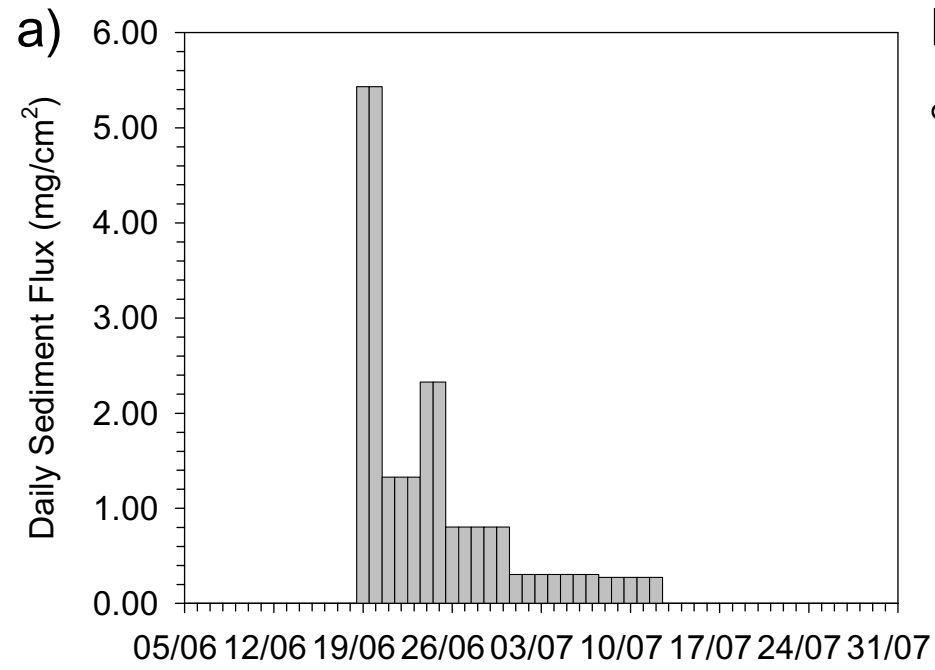

Date

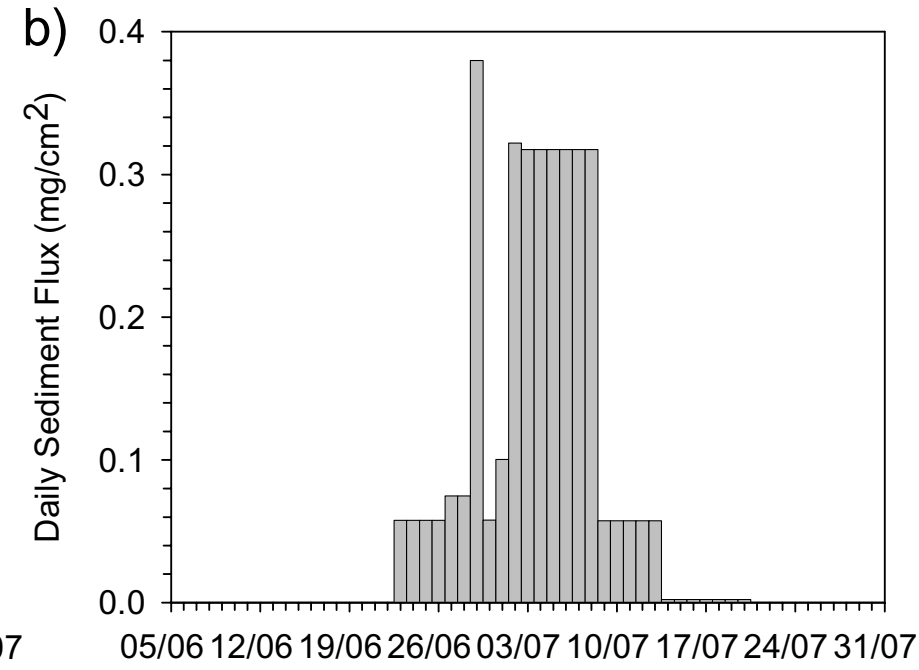

Date

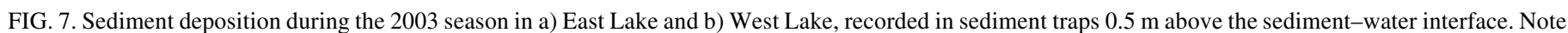

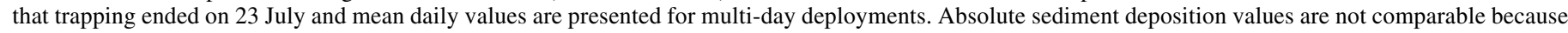
conditions differ in the two lakes.

By comparison, our observations suggest that sediment was deposited on the channel snow of the West Stream during initial ponding in June 2003 under low initial flow conditions, and remained, in part, until at least the end of June 2005. While multi-year or perennial snowbanks are common in the High Arctic (e.g., Lewkowicz and Young, 1990), storage of a substantial quantity of sediment within the snow has not been documented previously. The estimated initial $27 \mathrm{Mg}$ of sediment deposited on the snow in 2003 represents a significant portion of the sediment delivery in the West Stream that season. Downstream measurements indicate that a cumulative $42-55 \mathrm{Mg}$ of suspended sediment was transported past the gauging
TABLE 1. Summary of climate conditions recorded at Cape Bounty during the 2003-05 seasons.

\begin{tabular}{lrrr}
\hline \hline & 2003 & 2004 & 2005 \\
\hline Mean June temperature, MainMet $\left({ }^{\circ} \mathrm{C}\right)$ & -1.0 & -0.1 & 2.0 \\
West Stream watershed, SWE $(\mathrm{mm})$ & 43.3 & 82.0 & 55.1 \\
East Stream watershed, SWE $(\mathrm{mm})$ & 20.0 & 40.8 & 15.5 \\
\hline \hline
\end{tabular}

station prior to the establishment of sub-nival drainage and deposition of the sediment on 1 July 2003 (Fig. 8). This value is uncertain because the precise time of day when the stream changed from supra- to sub-nival flow is unknown. 


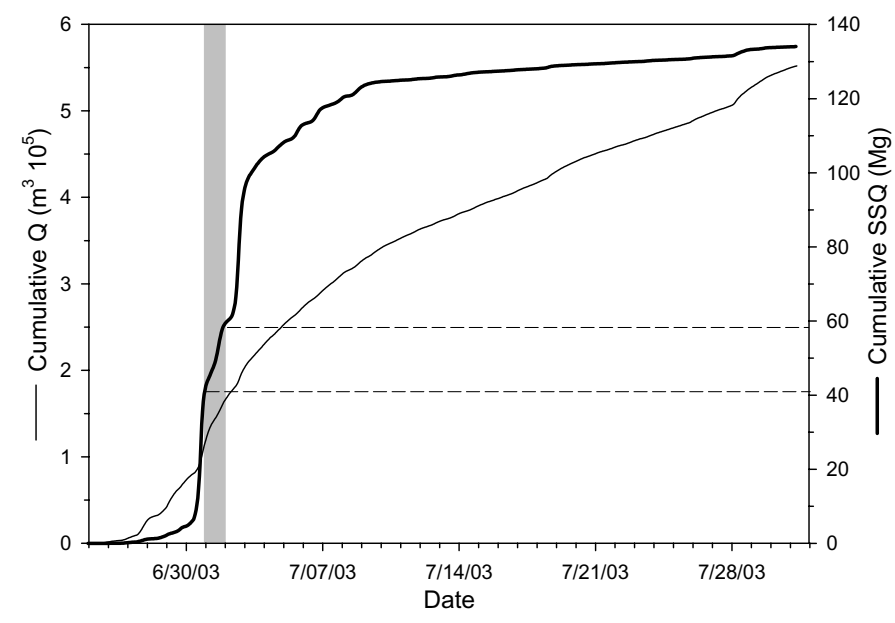

FIG. 8. Cumulative 2003 discharge (Q) and suspended sediment discharge (SSQ) for the West Stream determined by continuous stage monitoring and point measures of suspended sediment concentration. The shaded area represents 1 July and dashed lines show the cumulative SSQ limits for that day. The West Stream switched from a supra- to a sub-nival course at some time between midnight and 1800 on 1 July.

These estimates indicate that the sediment stored on the snow surface in 2003 represented $49 \%-65 \%$ of the sediment transported in the stream prior to the sediment abandonment. Moreover, the quantity of sediment stored in this small channel area represented an estimated $20 \%$ of the suspended sediment mass transported for the entire 2003 season (134 Mg at gauge station) (Fig. 8). These results indicate that sediment storage on the channel snowpack captured a significant portion of the sediment eroded and transported from upstream in the watershed. Hence, assuming that the stored sediment would otherwise have been transported past the gauging station, the abstraction to the channel snow reduced the sediment yield from the West Stream by at least $17 \%$.

The quantity of sediment deposited on the snow in the 2003 season was almost certainly much higher than our estimates indicate. Similar deposits of sediment on the channel snowpack were observed upstream of the study site as well, although they were significantly smaller in area. Unlike the channel snowpack at the study site, which was more than $4 \mathrm{~m}$ thick, the snowpack at these upstream locations was thinner, and most of it ablated during the course of the 2003 melt season. We observed numerous locations where thick sediment accumulations were left on the river channel from this snow ablation. However, because of the low discharge later in the season, when this sediment reached the channel bed, the stream was not in direct contact with the sediment (Church, 1972). This temporary sediment storage likely contributed to the 2004 or subsequent sediment load, although the early-season flow is characteristically limited to a narrow, snow-walled channel, and access to many areas of the channel bed is limited until the channel snowpack melts (Woo and Sauriol, 1981). Therefore, it is likely that some of the sediment deposited on the channel bed by slow melt of the snowpack remains for several seasons, and represents a form of multi-year sediment storage similar to what was observed on the channel snow.

The minimal sediment storage on the channel snowpack on the West Stream during the 2004 and 2005 seasons, as well as the absence of similar storage on the East Stream channel snow, indicates that this phenomenon is highly localized and may reflect a combination of channel morphological characteristics, snowpack attributes, and hydroclimatic conditions. In 2003, the snowpack in the West Stream channel was thick (> $4 \mathrm{~m}$ ) and a prominent snow dam was in place, but it is difficult to determine whether these conditions were unusual. Observations in 2004 and 2005 suggest that these are common conditions at the site, even though each study year had substantially different catchment SWE (Table 1). Similarly, the ponding that led to the deposition of the sediment on the snow may have been related to prevailing melt conditions. However, we observed that the ponding was similarly extensive in 2004, a cooler spring (Table 1), but little sediment was deposited. By contrast, 2005 was the warmest of the three years, and ponding lasted for only a few hours instead of days as observed in the previous two years. More broadly, the winters preceding the three seasons studied were characterized by the highest snowfall recorded at Mould Bay since 1950, although it is difficult to compare measurements taken before 1997 to the subsequent automated measurements. However, if the three study years 2003-05 represent relatively deep snowpacks, we postulate that concomitant increases in the quantity of snow in channel may increase the likelihood of meltwater ponding and sediment storage at the scale we observed.

\section{Channel Snow as a Geomorphic Agent}

Research has determined that in polar regions, in contrast to more temperate situations, channel snow plays an important role in modifying sediment delivery processes (McCann et al., 1972; Wedel et al., 1977; Woo and Sauriol, 1981; Woo, 1983; Threfall, 1987; Clark, 1988; Lewkowicz and Wolfe, 1994; Woo and McCann, 1994; Braun et al., 2000; Priesnitz and Schunke, 2002; Forbes and Lamoureux, 2005). In particular, initial flow through snow-lined channels isolates water from potentially erodible sediments (Woo and Sauriol, 1981). Initial channels in snow may shift rapidly as the season progresses, resulting in changes in the sediment delivery regime and sediment storage and release (Church, 1972).

All of these processes were apparent in the Cape Bounty streams. However, the magnitude of the sediment storage that we documented on the channel snow surface suggests that in some instances snow may play a large quantitative role in sediment storage and delivery. The absence of documented examples (e.g., Woo and Sauriol, 1981) limits comparison, but the interaction between snowpack sediment storage and release, stream discharge regime, and access to erodible sediment represents a complex system that varies each season and between similar water- 
sheds and channel systems. Woo and McCann (1994) note that the non-synchronous discharge and sediment transport patterns that prevail in Arctic nival systems limit predictions regarding the response of sediment delivery under changing climatic conditions. The differential response of the West and East streams to initial ponding and sediment storage in 2003 indicates that highly specific conditions control these processes. Generalizations are further complicated by the ephemeral nature of nival discharge and the alteration of channel flow by snow in subsequent years. Despite these complexities and uncertainties, the role of snowpack may represent an important link between hydroclimate conditions and sediment yield response in High Arctic watersheds.

\section{CONCLUSION}

In this study, we document the storage of sediment on channel snowpack during initial ponding of a small High Arctic stream. The mass of the sediment stored in a short reach of the stream represents a significant portion of suspended sediment transport for the season. The stored sediment remained, in part, for the next two seasons because of the thickness of the snow in the channel. Similar storage of sediment on snowpack has been described in the literature, and our estimates suggest that the mass of sediment stored is potentially high enough to affect the annual sediment budget. Further work is required to determine the quantitative impact of snow on sediment storage in nival watersheds.

\section{ACKNOWLEDGEMENTS}

This research was supported by grants from the Natural Sciences and Engineering Research Council of Canada and ArcticNet, and an Ontario Premier's Research Excellence Award to S.F. Lamoureux; Northern Scientific Training Program grants to D.M. McDonald, J.M.H. Cockburn, and D.M. Atkinson; and a Queen's ARC grant to M.J. Lafrenière. Analyses were supported by infrastructure grants from the Canadian Foundation for Innovation and the Ontario Innovation Trust. Logistical support was provided by the Polar Continental Shelf Project, Natural Resources Canada. We thank the Hamlet of Resolute for supporting our field research licence. Field assistance in 2003 by A. Forbes, G. Hambley, K. Stewart, and J. Wall is greatly appreciated. Constructive formal reviews by three anonymous reviewers improved the presentation of the paper. This is PCSP/EPCP contribution number 020-05.

\section{REFERENCES}

BRAUN, C., HARDY, D.R., BRADLEY, R.S., and RETELLE, M.J. 2000. Streamflow and suspended sediment transport into Lake Sophia, Cornwallis Island, Nunavut, Canada. Arctic, Antarctic, and Alpine Research 32:456-465.
CHURCH, M.J. 1972. Baffin Island sandurs: A study of Arctic fluvial processes. Bulletin 216. Ottawa: Geological Survey of Canada. 208 p.

CLARK, M. 1988. Periglacial hydrology. In: Clark, M., ed. Advances in periglacial geomorphology. Chichester: John Wiley. $415-462$.

FORBES, A.C., and LAMOUREUX, S.F. 2005. Climatic controls on streamflow and suspended sediment transport in three large middle Arctic catchments, Boothia Peninsula, Nunavut, Canada. Arctic, Antarctic and Alpine Research 37:305-315.

HEGINBOTTOM, J.A. 1984. The bursting of a snow dam, Tingmisut Lake, Melville Island, Northwest Territories. In: Current Research, Part B, Paper 84-1B. Ottawa: Geological Survey of Canada. 187-192.

HODGSON, D.A., VINCENT, J.-S., and FYLES, J.G. 1984. Quaternary geology of central Melville Island, Northwest Territories. Paper 83-16, Ottawa: Geological Survey of Canada. $25 \mathrm{p}$.

LEWKOWICZ, A., and WOLFE, P. 1994. Sediment transport in Hot Weather Creek, Ellesmere Island, NWT, Canada, 19901991. Arctic and Alpine Research 26:213-226.

LEWKOWICZ, A.G., and YOUNG, K.L. 1990. Hydrology of a perennial snowbank in the continuous permafrost zone, Melville Island, Canada. Geografiska Annaler 72A:13-21.

McCANN, S.B., HOWARTH, P.J., and COGLEY, J.G. 1972. Fluvial processes in a periglacial environment, Queen Elizabeth Islands, NWT, Canada. Transactions of the Institute of British Geographers 55:69-82.

PRIESNITZ, K., and SCHUNKE, E. 2002. The fluvial morphodynamics of two small permafrost drainage basins, Richardson Mountains, northwestern Canada. Permafrost and Periglacial Processes 13:207-217.

SYVITSKI, J.P.M. 2002. Sediment discharge variability in Arctic rivers: Implications for a warmer future. Polar Research 21: $323-330$

THREFALL, J.L. 1987. The relationship between discharge and suspended sediment in a small nival Subarctic catchment. In: Gardiner, V., ed. International geomorphology 1986. Chichester: John Wiley. 823-841.

WALKER, D.A., RAYNOLDS, M.K., DANIËLS, F.J.A., EINARSSON,E.,ELVEBAKK, A., GOULD, W.A., KATENIN, A.E., KHOLOD, S.S., MARKON, C.J., MELNIKOV, E.S., MOSKALENKO, N.G., TALBOT, S.S., YURTSEV, B.A., and the other members of the CAVM Team. 2005. The circumpolar Arctic vegetation map. Journal of Vegetation Science 16: $267-282$.

WEDEL, J.H., THORNE, G.A., and BARACOS, P.C. 1977. Site intensive hydrologic study of a small catchment on Bathurst Island (Interim Report 1976). Hydrologic Regimes Freshwater Project No. 1 (FP-1-76-1). Ottawa: Western and Northern Region, Inland Waters, Environment Canada. 122 p.

WOO, M.-K. 1983. Hydrology of a drainage basin in the Canadian High Arctic. Annals of the Association of American Geographers 73:577-596.

WOO, M.-K., and McCANN, S.B. 1994. Climatic variability, climatic change, runoff, and suspended sediment regimes in northern Canada. Physical Geography 15:201-226. 
WOO, M.-K., and SAURIOL, J. 1980. Channel development in snow-filled valleys, Resolute, N.W.T. Geografiska Annaler 62A:37-56.

1981. Effects of snow jams on fluvial activities in the High Arctic. Physical Geography 2:83-98.
WOO, M.-K., LEWKOWICZ, A.G., and ROUSE, W.R. 1992. Response of the Canadian permafrost environment to climatic change. Physical Geography 13:287-17. 